\title{
Dominant factors for the marketing of private higher education
}

\author{
Ragil Pardiyono ${ }^{a^{*}}$, Jaja Suteja ${ }^{\mathrm{b}}$, Hermita Dyah Puspita ${ }^{\mathrm{a}}$ and Undang Juju ${ }^{\mathrm{b}}$
}

\begin{abstract}
${ }^{a}$ Department of Industrial Engineering, Universitas Jenderal Achmad Yani, Bandung, Republic of Indonesia ${ }^{b}$ Department of Management, Universitas Pasundan, Bandung, Republic of Indonesia

C H R O N I C L E Article history:

Received August 1, 2021

Received in revised format: November 10, 2021

Accepted December 12021

Available online

December 2, 2021

Keywords:

Marketing mix

Internal marketing

External marketing

Higher education

SEM-PLS

A B S T R A C T

Higher education institutions, like any business institution, should satisfy their clients (students) for them to survive in the higher education service business market. As a service business, higher education institutions also need to follow marketing principles in their attempt to attract potential students. We investigated the effect of marketing mix dimension on internal and external marketing in universities. The research used primary data from a questionnaire survey of 526 students in West Java Province, Indonesia, and then drew conclusions by a structural equation model (SEM) analysis. The research findings revealed that place, product, price and promotion have a positive effect on external marketing. Whereas physical evidence, people and processes have positive, significant effects on internal marketing. There was also positive, significant correlation between external marketing and internal marketing. The research findings were hopefully beneficial for higher education management, to be made as guidance in implementing their marketing strategy. Higher education leaders may apply the external marketing policy to attract potential student interest and the internal marketing policy to improve the quality of their service and internal marketing. The study delivered a broader picture of the application of marketing mix model on universities. In addition, the discussion presented the implication of the offered theory and practice, the research limitation, and the direction of future researchers.
\end{abstract}

C 2022 by the authors; licensee Growing Science, Canada

\section{Introduction}

In the current decade, universities in Indonesia have been growing rapidly in number. In 2020, there were 4,593 universities in total. The growing numbers of universities affected the competition between universities. Some universities were eventually closed, being the loser in such competition (source: https://www.cnnindonesia.com). Higher education institutions, like other business institutions, must satisfy their clients (students) to survive in the service business market (Chawla, 2013). According to Durkin and McKenna (2011) universities need to follow marketing principles in their attempt to attract potential students. According to Gajić (2012) the education sector has to change marketing strategy as a consequence of dynamics in competition. If universities want a dynamic change they should concentrate on student expectations and hopes in their marketing (Hall \& Witek, 2016). Pain's opinion Stimac and Simic (2012) and Sousa and Magalhães (2019) agree that higher education institutions should develop a marketing strategy to win competition.

Strict competition in student recruitment has created a strong need for higher education institutions. Based on the reference above, it could be concluded that private universities as a higher education service industry need to develop a sound marketing strategy. According to Chawla (2013), Filip (2012) and Ndofirepi et al. (2020). A set of marketing mix variables were recommended to universities for them to choose one in recruiting potential students and in designing their marketing strategy. Marketing mix is a set of marketing instruments a company mixes so as to produce responses the targeted market wants, the dimensions of which

* Corresponding author.

E-mail address: ragil.pardiyono@lecture.unjani.ac.id (R. Pardiyono)

(C) 2022 by the authors; licensee Growing Science, Canada.

doi: $10.5267 / \mathrm{ds} 1.2021 .12 .002$ 
include product, price, promotion, place, process, people, and physical evidence Kotler et al (2016). According to Kavididevi, (2009) who carried out a research into marketing strategy by using marketing mix in Chester, Hunddersfield and Staffordshire University, the aspects whose service quality have to be maintained and improved in order to successfully attain and retain students were: Product (Degree Awarded), Price (Course Fees), Place (Coaching Place, Accommodation Service), Promotion (Advertising, Internet Marketing, Brochures), Process (Administrative Processes, Student Enrolment), People (Face-to-face communication, Personal contact), and Physical Evidence (Brochures, Teaching Material). Another research into marketing mix in higher education was carried out by Lim et al. (2020) at School of Business, Swinburne University of Technology, Sarawak, Malaysia, concluding that prominence, excellence, prospectus, program, price, people, premium, and promotion have positive, direct effect on the selection of program study, but people, quality, and promotion elements have insignificant effect.

The present research was grounded on a perception that the marketing mix model does not completely represent the ways of university marketing. Therefore, it would examine the effects of all dimensions of the marketing mix model (product, price, promotion, place, process, people, and physical evidence) on university marketing. A partial least squares structural equation modelling (PLS-SEM) technique is deployed to examine these relationships. Research communities believe that PLS is superior to other techniques in analyzing small size samples or data with non-normal distribution (Goodhue et al., 2012). The research findings would deepen understanding on supporting factors in university marketing in attracting potential student interest and in retaining students.

Partial least squares (PLS) is an important statistical technique in the empirical analysis method of marketing research and other social sciences (Hair, 2019). In PLS, it is assumed that all variance measures are valuable to explain, because an approach of estimating latent variables is deemed a linear combination of indicators. PLS uses an algorithm iteration consisting of PLS serial considered as an alternative model of covariance based SEM. There are two approaches in SEM, namely, covariance-based SEM and SEM with a variance approach that uses Partial Least Squares (PLS) technique. The present research used PLS which was a type of analysis of component-based SEM with a formative variable nature and serves only as a predictor analysis instrument. The PLS method is also known as prediction-oriented technique. PLS approach is particularly useful in predicting dependent variables by involving some independent variables (Lee, 2011).

\section{Literature review}

\subsection{Theoretical background and hypotheses}

The success or failure of an organization in achieving its goals depends on the marketing strategy applied. An instrument usable in developing a marketing strategy is the marketing mix method. McCharthy, in 1964, developed a 4P (product, price, promotion and place) marketing mix model. It was developed for the marketing of products produced by manufacturing industries (Goi, 2009). Over time, it has been used not only by manufacturing industries but also by the service industry. To accommodate service characteristics, Booms and Bitner developed a marketing mix model for the service industry in 1980, by broadening 3P to 7P (product, price, promotion, place, process, people, and physical evidence) (Goi, 2009). The base model to be the reference of the present research was 7P the marketing mix model for service industry, consisting of seven dimensions.

The 7P marketing mix model was relevant in the research because the dimensions used were able to represent service industry characteristics. The marketing mix concept on service companies is grouped into two areas, that is, external and internal marketing (Schulz et al., 2017; Christopher et al., 2013). In the present research we involved the two areas, that is, external marketing and internal marketing. The external marketing focused on the measures of attracting the interest of potential students so that they decide to choose the university. The marketing mix dimensions appropriate to external marketing are place, price, product and promotion (Christopher et al., 2013). The second area, internal marketing, focused on academic and non-academic service quality. Internal marketing needs to be improved because higher education institutions, like any business institution, should satisfy its clients (students) for it to survive in the business/service market (Chawla, 2013). If students perceive that the services they receive are good, from enrollment to post-graduation, then they will most likely recommend others to enroll in the university. The relevant dimensions with internal marketing are process, people, and physical evidence. Combining both internal marketing and external marketing would be the best formulation to developing a marketing strategy, because internal marketing and external marketing go in parallel and complementary in optimizing university marketing.

\subsection{Research hypothesis development}

Based on the base model above, below was developed some hypotheses to find the answers to the research purpose. Fig. 1 presented an inter-variable hypothesis model. There were 8 hypotheses to test in the next stage. The hypotheses were as follows,

\section{Hypothesis 1: Place has a positive effect on external marketing.}

Place in the present research was defined as the place where interaction and learning between students, lecturers, and academic staff are taking place. Its measurement indicators are: accessibility of campus location by public vehicles, close to public facilities and campus location, and clean and neat campus location (Christopher et al., 2013; Gordon, 2012).

Hypothesis 2: Product has a positive effect on external marketing.

Product means all education services offered to potential students. The measurement indicators of product variables are: awarding of appropriate degrees, diverse study programs, study programs offered to meet market needs, availability of a standard term of finishing study, and gives advice on finishing study on time (Christopher et al., 2013; Isoraite, 2016).

Hypothesis 3 : Price has a positive effect on external marketing. 
Price is meant the cost paid by students for attending an education program in a university. The measurement indicators of the variable are: inexpensive tuition, less tuition relative to that in other campuses, the payment of tuition that may be paid in installments, easy payment method, and availability of scholarship from internal and external sources (Christopher et al., 2013; Singh, 2012; Gajic, 2012).

Hypothesis 4 : Promotion has a positive effect on external marketing.

Promotion is all activities and communication performed to introduce a university to public and potential students. Its measurement indicators are: socialization by printed media (newspaper), electronic media, Internet, brochures, banners, and school visitation (Christopher et al., 2013; Singh, 2012; Gajic, 2012).

Hypothesis 5: Physical evidence has a positive effect on internal marketing.

According to Christopher et al. (2013) and Asiegbu et al. (2012) physical evidence is resources and environment where academic services are provided. Its measurement indicators are: availability of textbooks for the courses offered, easy access to scientific journals, clean and comfortable classrooms, and complete and accessible laboratories.

\section{Hypothesis 6: People has a positive effect on internal marketing.}

By People is meant as those who are directly involved in performing the whole university activities and to be a factor with important roles in their organization (Pardiyono \& Indrayani, 2019; Ogunnaike, 2014). Its measurement indicators are: mentoring lecturers are always concerned with the success of their students, department heads always help students in completing their study, campus staff is always attentive and helpful in serving student needs, library staff always helps students, and registration officers are friendly and very helpful to students.

Hypothesis 7: Process has a positive effect on internal marketing.

Meant by Process is the measures taken by private universities to perform their activities in a bid to meet their consumers' needs and wants quickly and correctly (Pardiyono \& Indrayani, 2019; Ogunnaike, 2014). Its measurement indicators are: course materials match the syllabus, lecturing sessions are always on time, evaluation and final scoring are objective, availability of good learning online, and students are allowed to take examinations for upgrading their score.

\section{Hypothesis 8: External marketing has a positive effect on internal marketing.}

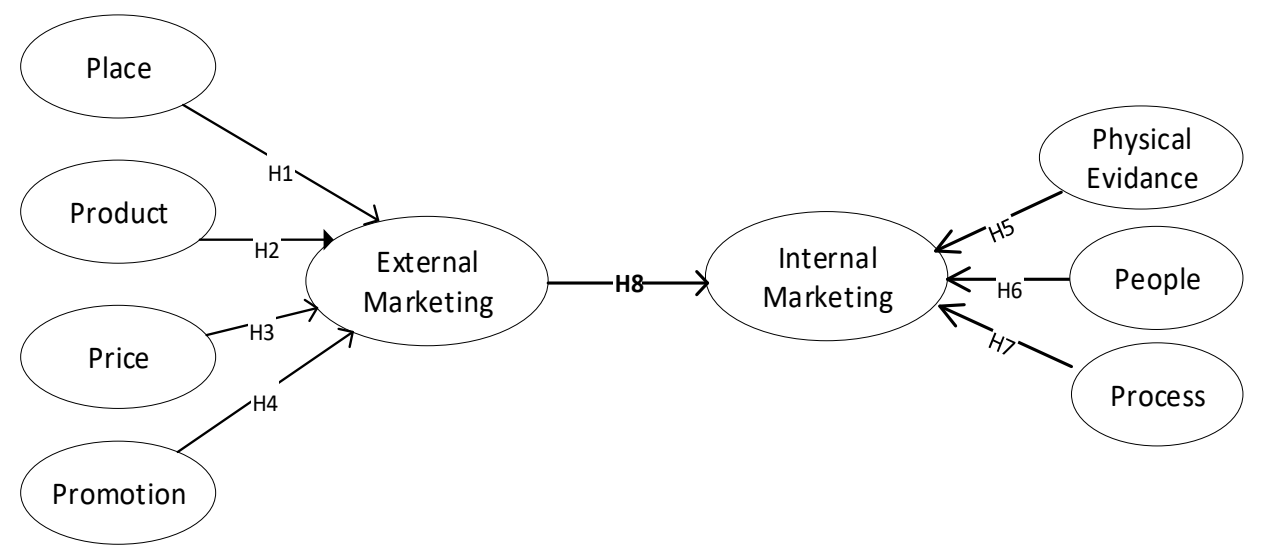

\section{Methodology}

Fig. 1. Hypotheses Model

\subsection{Instrument development}

The data collection was conducted by using a questionnaire, in the form of a list of written questions or statements made in accordance with the variables to be investigated (Sekaran \& Bougie, 2019). The core of a survey is a questionnaire, which describes samples for conversations between the researcher and respondents. The findings of a survey highly depend on the questionnaire. To minimize errors in responses, a questionnaire has to be made well Singh, (2017), his research questionnaire used a five-point likert scale questionnaire to find the answers to the research purpose, i.e., 1 means strongly disagree, 2 disagree, 3 don't quite agree, 4 agree, and 5 strongly agree.

The research questionnaire used both closed and open questions. Closed questions are ones which restrict the respondents in answering questions, whereas open questions are ones which give freedom to the respondents in answering questions according to what they know (Crhabanski, 2014). The questionnaire content is divided into two parts. Part one contains respondent data, such as email, age, sex, and university of origin. Part two contains assessment of campus marketing and services. Before being used as a data collection instrument, the questionnaire had been validation- and reliability-tested by trying it out to 30 respondents. 


\subsection{Sampling and Data Collection}

The research population was the students of private universities in West Java Province, Indonesia. There were 372 higher education institutions in West Java Province (Source: Statistic Higher Education Republic of Indonesia, 2020) Research sampling used a multi-strata random sample, that is, the population was divided into strata (sub-population). The technique was used for nonhomogenous, multi stratum population proportionally (Hirpassa, 2015). The universities are highly diverse, so one thing that can differentiate them is the number of active students of each university. Thus, the population was classified into three groups: group 1 was universities with the number of active students of $>5,000$, group 2 from 1,000 to 5,000, and group $3<1,000$.

The determination of a minimum number of samples used a counting of 5 times the number of manifest variables (Black \& Babin, 2019). The variables identified were 32 manifest variables, so the minimal number of samples was 160 respondents. Questionnaire spreading used google form to 600 students of 20 private universities, but the questionnaires returned and completely filled out were 526, consisting of 4 universities with total students above 5000, 7 with students between 1000 and 5000, and 9 with students $<1000$. The research data processing used Structural Equation Modeling - Partial Least Square (SEM-PLS), which is a powerful analysis method because it is applicable to all data scales and does need lots of assumptions (Afthanorhan, 2013). Convergent validity was used to measure uniformity between latent variable and manifest variable used according to concepts and theories. The measurement of convergent validity may use the results of PLS algorithm processing, namely outer loading, reliability construct, and average variance extracted (AVE). Outer loading is a measurement which contains the loading factor of the manifest variable that shows the extent of the correlation between manifest variable and latent variable. If the measurement of validity with outer loading can be met, that is, above 0.7 (Nfuka \& Rusu, 2011), then further tests can be performed. Measurement of convergent validity was then performed by Construct Reliability test. A good and reliable Construct Reliability has Composite Reliability value greater than 0.7 (Cao et al., 2015; Huang et al., 2013). Convergent validity test was then performed by using average variance extracted (AVE) value, which indicates the average community (variance) for each independent factor in the reflective model. AVE value must be greater than 0.5 (Shau, 2017; Huang et al., 2013).

Structural model is a model which connects independent variables with dependent variables or between one dependent variable with another. Independent variable is one considered as having effect on other variables, but is not affected by other variables in the model. The values used in the structural model are: a) R-Square value, explaining to the extent of which the independent variable hypothesized in the equation is able to explain the dependent variable. If $\mathrm{R}^{2}$ is greater than 0.7 then it is categorized as high, meaning that the model produced has a value with a good uniformity (Huang et al., 2013). b) Q-square is computed to evaluate a path model. If $\mathrm{Q}$-square is greater than null then the model has a predictive significance and $\mathrm{Q}^{2}$ value is found by the following equation: $\mathrm{Q}^{2}=1-\left(1-\mathrm{R}_{1}^{2}\right)$ (Silaparasetti et al., 2017).

\section{Results and discussion}

\subsection{Respondents' Demography}

The demography variables considered in the research were sex, age, and university of origin. The respondents' demographic information was presented on the Fig. 2 below:

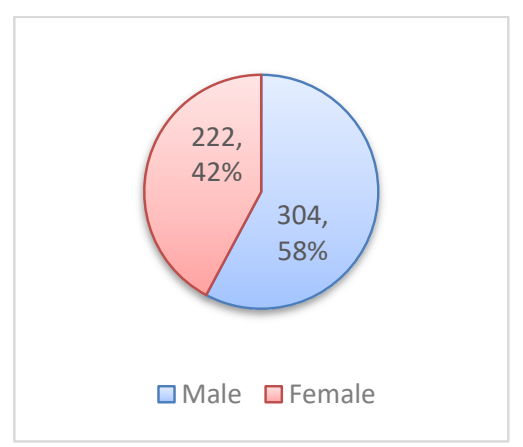

Gender

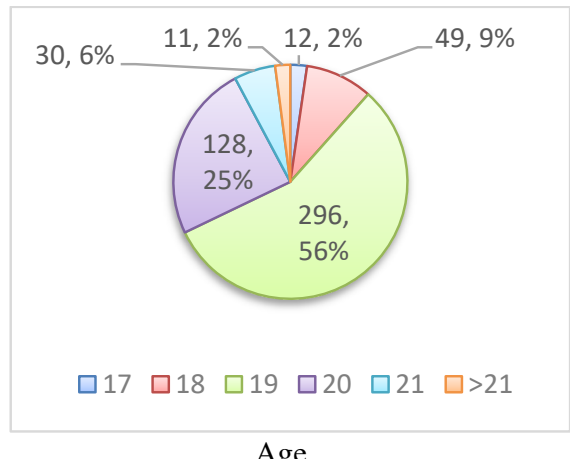

Age

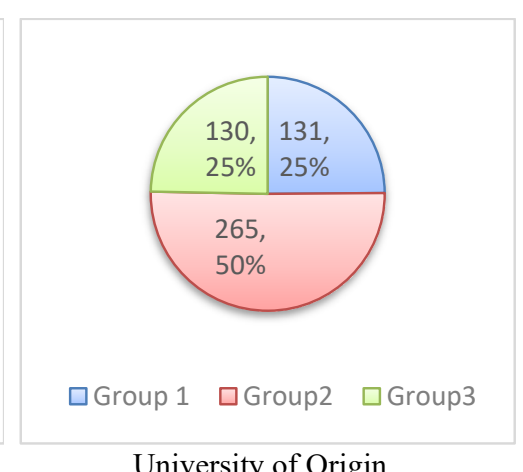

University of Origin

\subsection{Hypotheses testing}

Fig. 2. Personal characteristics of the participants

Hypothesis testing is a procedure of generating a decision (accepting/rejecting the hypothesis). After having performed an analysis by using a path diagram, next is to run value bootstrapping on a path diagram to find a value to be t-tested for its significance. If the $t$ value of structural equation is $\geq 1.96$ then it is concluded that there is a significant effect of the independent variable on its dependent variables (Chen et al., 2014). The outer loading of all dependent variables on external marketing showed values $>0.7$ except for PM1 variable, that is, campus carried out socialization by newspaper, and PM5 variable, that is, campus carried out socialization by banners/billboard, both being of value $<0.7$, so the dependent variables should be reduced (Huang et al., 2013). On the outer loading of internal marketing variables there were no variables with value less than 0.7 , so the model has been valid, meaning that there has been conformity between the independent variable and the dependent variables. The results of the outer loading values of all internal marketing and external marketing were presented on Table 1. 
Table 1

List of item with factor loading

\begin{tabular}{|c|c|c|c|}
\hline Constructs & Kode & Item description & Loading \\
\hline \multirow[t]{3}{*}{ Place } & P11 & Campus location is easily accessible to public vehicles & 0.853 \\
\hline & $\mathrm{P} 12$ & Campus location is close to public facilities & 0.752 \\
\hline & $\mathrm{P} 13$ & Campus location is clean and neat & 0.887 \\
\hline \multirow[t]{4}{*}{ Product } & Pd1 & Campus awards appropriate degrees & 0.811 \\
\hline & $\mathrm{Pd} 2$ & Campus offers diverse study programs & 0.745 \\
\hline & $\mathrm{Pd} 3$ & Study programs offered meet market needs & 0.808 \\
\hline & $\mathrm{Pd} 4$ & Campus set a standard term of finishing study and gives advice on finishing study on time & 0.876 \\
\hline \multirow[t]{5}{*}{ Price } & Pc1 & Inexpensive tuition & 0.887 \\
\hline & Pc2 & Tuition is inexpensive relative to that in other campuses & 0.879 \\
\hline & Pc3 & The payment of tuition that may be paid in installments according to student capacity & 0.881 \\
\hline & Pc4 & Easy payment procedure and method & 0.873 \\
\hline & Pc5 & Availability of scholarship from internal and external sources & 0.846 \\
\hline \multirow[t]{5}{*}{ Promotion } & Pm1 & The university makes by printed media (newspaper) & 0.635 \\
\hline & $\operatorname{Pm} 2$ & The university makes by electronic media & 0.878 \\
\hline & Pm3 & The university makes by Internet & 0.871 \\
\hline & $\mathrm{Pm} 4$ & The university makes by brochures and banners & 0.630 \\
\hline & Pm5 & The university makes by school visitation & 0.846 \\
\hline Physical & PE1 & The university makes available textbook for the courses offered & 0.769 \\
\hline \multirow{4}{*}{ Evidence } & PE2 & Availability of sufficient learning facilities & 0.871 \\
\hline & PE3 & Easiness to access scientific journals & 0.973 \\
\hline & PE4 & Clean and comfortable classroom & 0.924 \\
\hline & PE5 & Complete and accessible laboratory & 0.939 \\
\hline \multirow[t]{5}{*}{ People } & Peo1 & Mentoring lecturers always concern with their own student success & 0.897 \\
\hline & Peo2 & Head of Department is always helpful to students in finishing their study & 0.845 \\
\hline & Peo3 & Campus staff is always attentive and helpful in serving student needs & 0.857 \\
\hline & Peo4 & Library staff always helps students & 0.769 \\
\hline & Peo5 & Registration officers are friendly and very helpful to students & 0.784 \\
\hline \multirow[t]{5}{*}{ Process } & Pro1 & Course materials match the syllabus & 0.994 \\
\hline & Pro2 & Lecturing sessions are always on time & 0.914 \\
\hline & Pro3 & Evaluation and final scoring are objective & 0.877 \\
\hline & Pro4 & Availability of good learning online & 0.900 \\
\hline & Pro5 & Students are allowed to take examination for upgrading their score & 0.845 \\
\hline
\end{tabular}

\subsection{Convergent validity}

Convergent validity is aimed to find the correlation between the indicators and their independent variable performed by construct reliability test. The Construction reliability test used two measurements namely average variance extracted (AVE) with composite reliability. A construct's reliability is good and reliable if the composite reliability value is greater than 0.7 (Cao et al., 2015 ; Huang et al., 2013). The test result showed that all variables were of composite reliability greater than 0.7 , so all the research variables could be used.

Next, the convergent validity test used average variance extracted (AVE) value. This value indicates the average communality (variance) for each independent factor in a reflective model. It was found from the result of the test that the value of AVE $>0.5$, meaning that the information contained in the dependent variables could be reflected by the independent variable (Abalala et al., 2021; Alwreikat \& Rjoub, 2020; Shau, 2017; Huang et al., 2013). Given that composite reliability $>0.7$ and AVE value $>0.5$, the model could be said to be reliable. Presented on the following Table 2 is the summary of composite reliability (CR) and average variance extracted (AVE) values.

Table 2

Convergent validity test

\begin{tabular}{ccc}
\hline Constructs & CR & AVE \\
\hline Place (Pl) & 0.896903 & 0.841466 \\
Product (Pd) & 0.779912 & 0.871667 \\
Price (Pc) & 0.851194 & 0.839544 \\
Promotion (Pm) & 0.773296 & 0.870583 \\
Physical Evidence (PE) & 0.989677 & 0.765414 \\
People (Peo) & 0.771671 & 0.870624 \\
Process (Pro) & 0.879063 & 0.83548 \\
\hline
\end{tabular}

\subsection{Structural Model (Inner Model) Test}

\section{$R$-Square}

$\mathrm{R}$-Square or $\mathrm{R}^{2}$ values of dependent variables show the extent of effect/conformity of the independent variable in affecting the dependent variables. $\mathrm{R}^{2}$ value explains to the extent of which the independent variable hypothesized in equation is able to explain the dependent variables. 
Table 3

Direct Effect, Indirect Effect, and R-Square

\begin{tabular}{|c|c|c|c|}
\hline Path & Direct Effect & Indirect Effect & R-Square \\
\hline External Marketing $(\mathrm{X}) \rightarrow$ Internal Marketing $(\mathrm{Y})$ & 0.895 & & 0.801835 \\
\hline
\end{tabular}

The value of direct effect of External Marketing on Internal Marketing was 0.895, meaning that External Marketing has positive effect of $89.5 \%$ on Internal Marketing. $\mathrm{R}^{2}$ value was 0.80 , falling into a category of "high". It showed that the value yielded by the model has a good conformity (Huang et al., 2013).

\section{Q-Square Predictive Relevance}

The computation of $\mathrm{Q}^{2}$ value found a value of 0.8 , meaning that the research model has a good predictive relevance, because $\mathrm{Q}^{2}$ value $>0$, meaning that the independent variable has a predictive level falling into a category of good on the dependent variables.

$$
\mathrm{Q}^{2}=1-\left(1-\mathrm{R}_{1}^{2}\right)=1-(1-0.80)=0.8
$$

\subsection{Hypothesis Testing}

Hypothesis testing was performed after the variables with loading value of less than 0.7 had been reduced, namely Pm 1 and Pm5 variables. The testing is a procedure of generating a decision (accepting/rejecting the hypothesis). The findings on the effect of place variable on table 5 showed a positive correlation and significant effect on external marketing $(\beta=0.689, \mathrm{p}=0.013, \mathrm{t}=2.971)$. It means that hypothesis 1 was accepted. The same result also applied to hypothesis 2 , that is, the product variable has a positive correlation and significant effect on external marketing $(\beta=0.794, \mathrm{p}=0.000, \mathrm{t}=18.578)$. Price variable $(\beta=0.910, \mathrm{p}=0.000, \mathrm{t}=13.583)$ in hypothesis 3 showed a positive, significant correlation with external marketing. Hypothesis 4 , promotion variable $(\beta=0.813$, $\mathrm{p}=0.001, \mathrm{t}=14.357$ ) has a positive, significant effect on external marketing, was also accepted. The Fig. 3 below also showed that place variable was responsible for $47.5 \%$ of external marketing dimension, product variable for $63 \%$, price variable for $83.8 \%$ and promotion variable for $83.3 \%$

The findings on internal marketing showed that physical evidence has $\beta=0.530, p=0.001$, and $\mathrm{t}=5.171$; people variable has $\beta=0.675, p=0.006$, and $\mathrm{t}=9.418$ ); and process variable has $\beta=0.579, \mathrm{p}=0.031$, and $\mathrm{t}=7.015$. It meant that physical evidence, $p$ eople and process variables have positive, significant effects on internal marketing. Fig. 3 also showed that the physical evidence variable was responsible for $29.1 \%$ of the internal marketing dimension, the people variable for $49.9 \%$, and process variable for $78.4 \%$. The value of $t$-count on the effect of external marketing on internal marketing was $19.9055>t$-table (1.96), so hypothesis 8 was accepted, that is, there was effect of external marketing variable on internal marketing. The effect fell into a category of high and of positive value. It means that the higher the external marketing variable, the higher the internal marketing variable. Factor loadings of the indicators and t-count were presented on Fig. 3 and Fig. 3.

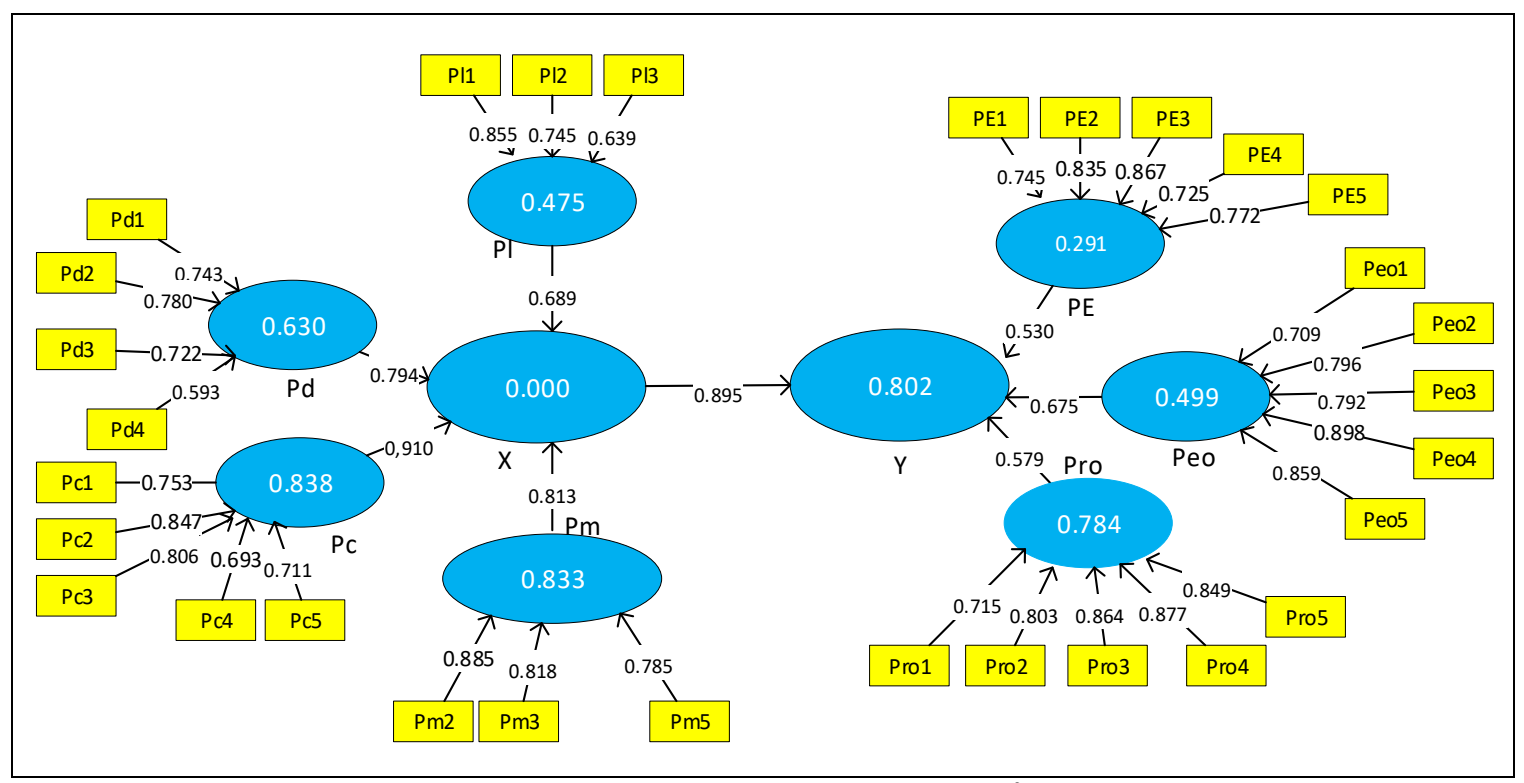

Fig. 3. Factor loadings of the indicators, beta, and $\mathrm{R}^{2}$ values 


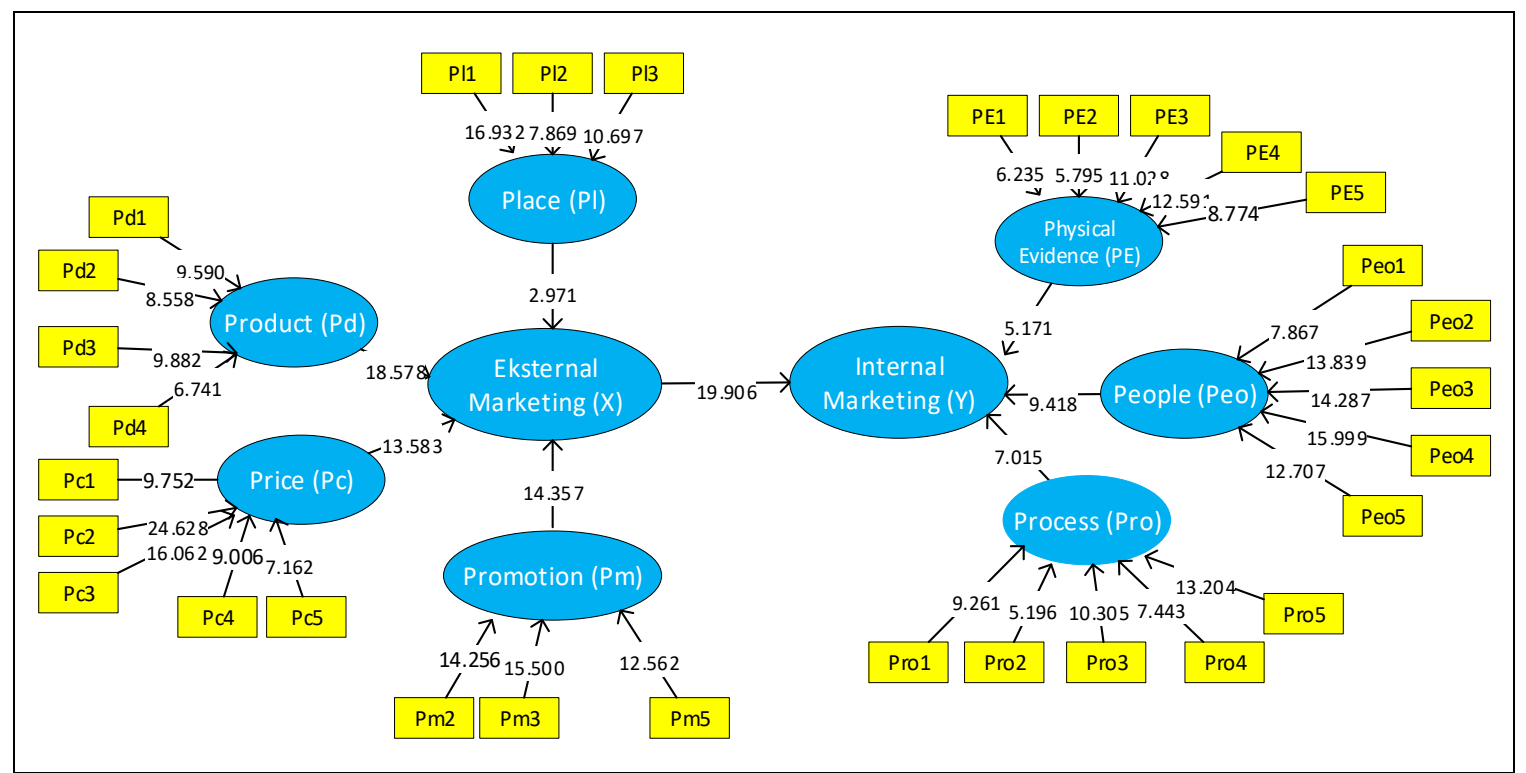

Fig. 4. T-statistics of the indicators and beta coefficients

Table 4

Direct effects

\begin{tabular}{llcccc}
\hline \multicolumn{1}{c}{ Independent Variable } & Dependent Variable & $\boldsymbol{\beta}$ & $\boldsymbol{t}$ & $\boldsymbol{p}$ & Decision \\
\hline H1: Place $(\mathrm{Pl})$ & $\rightarrow$ External Marketing $(\mathrm{X})$ & 0.689 & 2.971 & 0.013 & Supported \\
H2: Product $(\mathrm{Pd})$ & $\rightarrow$ External Marketing $(\mathrm{X})$ & 0.794 & 18.578 & 0.000 & Supported \\
H3: Price (Pc) & $\rightarrow$ External Marketing (X) & 0.910 & 13.583 & 0.000 & Supported \\
H4: Promotion (Pm) & $\rightarrow$ External Marketing (X) & 0.813 & 14.357 & 0.001 & Supported \\
H5: Physical Evidence (PE) & $\rightarrow$ Internal Marketing (Y) & 0.530 & 5,171 & 0.012 & Supported \\
H6: People (Peo) & $\rightarrow$ Internal Marketing (Y) & 0.675 & 9,418 & 0.006 & Supported \\
H7: Process (Pro) & $\rightarrow$ Internal Marketing (Y) & 0.579 & 7,015 & 0.031 & Supported \\
H8: External Marketing (X) & $\rightarrow$ Internal Marketing (Y) & 0.895 & 19,9055 & 0.000 & Supported \\
\hline
\end{tabular}

\subsection{Discussion}

The research was the first in university marketing with the greatest number of respondents in Indonesia. The survey aimed to examine the structural correlation between external marketing and internal marketing, together with their indicators. The findings would hopefully be useful for the development of theories on marketing in universities, like splitting marketing mix into external marketing and internal marketing. The external marketing focused on attracting potential student interest, while the internal marketing focused on services to active students. The findings would generate the best formulation for developing marketing strategy, because the activities of both internal and external marketing go in parallel and complementary to optimize university marketing. The present research examined whether or not place, product, price and promotion have an effect on potential student interest in choosing a university by external marketing activities. We also examined whether physical evidence, people and process affected service quality on active students so that they would "feel at home" and recommend it to other potential students.

First, place was responsible for $47.5 \%$ and has a positive effect on external marketing activities. The finding was in agreement with that of Brkanlic et al. (2020), Kavididevi et al. (2009), Chawla (2013) and Ndofirepi et al. (2020). It also validated Christopher et al. (2013) and Gordon, (2012) that the indicator on place variable was the reason for potential students in deciding their campus. Second, we found that the product had a positive effect and was responsible for $63 \%$ of external marketing. The finding was in agreement with that of prior researches by Hawkins \& Frohoff (2010) and Lim et al. (2020) also validated Christopher et al. (2013) and Isoraite (2016) that the indicator of product variable was the reason for potential students to enroll in a particular university.

Further finding on external marketing was that price has positive correlation with and responsible for $83.8 \%$ of external marketing. It was in agreement with that of Brkanlic et al. (2020), Al-Fatah (2010), Lim et al. (2020), and Ndofirepi et al. (2020) also validated Christopher et al. (2013), Singh (2012) and Gajic (2012) that price variable was the reason for potential students in choosing a university. On the other side, though promotion variable has positive, significant correlation in agreement with Brkanlic et al. (2020), Durkin and Mckenna (2011), Lim et al. (2020) and Ndofirepi et al. (2020) but there were variables reduced because their value was $<0.7$, namely Pm1 (University carried out socialization by printed media (newspaper), and Pm5 (university campus carried out socialization by brochures/banners). The reduction of both PM1 and PM5 variables is understandable given that now a majority of people prefer social media and the internet to printed media. The finding was in agreement with that of Domazet et al., (2017), that is, promotion with the weakest effect was by printed media and brochures. Thus, for promotion, some findings Christopher et al. (2013), Singh (2012) and Gajic (2012) were not validated, only a few findings which were in agreement, that is, universities need to carry out socialization by electronic media, Internet, and school visitation. 
On internal marketing it was found that physical evidence has positive, significant correlation. It was in agreement with Ndofirepi et al. (20200, Kavididevi et al. (2009), and Brkanlic et al., (2020). It also validated Christopher et al. (2013) and Asiegbu et al., (2012) that the indicator of physical evidence variable might improve quality service and student satisfaction. Second finding on internal marketing was that people had positive correlation, in agreement with Lim et al., (2020), Brkanlic et al., (2020) and Kavididevi et al. (2009). Some services to enhance for internal marketing strategy were people variable, that is, mentoring lecturers always concern with their student success, head of department is always helpful to students in finishing their study, campus staff is always attentive and helpful in serving student needs, library staff always helps students, and registration officers are friendly and very helpful to students (Ogunnaike, 2014).

The third on internal marketing was that the process has positive, significant correlation with internal marketing, in agreement with Ndofirepi et al. (2020), Kavididevi et al. (2009), and Brkanlic et al. (2020). The finding also validated Ogunnaike, (2014) the indicator of process variable might improve service quality and marketing. Hypothesis tests directly between external marketing variable and internal marketing variable showed positive, strong correlation between the two. It was in agreement with Ahmde \& Rafiq (2013), Schulz et al. (2017) and Christopher et al. (2013) that internal marketing was one of the methods of achieving consistent service quality. Application of the concept has been growing not only in the service area but also in facilitating the application of external marketing strategy.

\subsection{Implications for theory and practice}

The implication of the research findings to all university management was that they can utilize the findings to be made as guidance in implementing their marketing strategy. Higher education leaders may take policies in external marketing to attract potential student interest by implementing the research findings. Based on the findings on external marketing, university management should carry out and improve the place aspect (campus location is easily accessed by public vehicles, close to public facilities, clean and neat). Next was product (appropriate degrees, diverse study programs, study programs offered to meet market needs, and availability of a standard term of finishing study. Next was price (inexpensive tuition, less tuition relative to that in other campuses, may be paid in installments, easy payment method, and availability of scholarship from internal and external sources. The last was promotion (universities should carry out socialization by electronic media, Internet, and school visitation).

Second, university management may adopt the findings on internal marketing to focus on academic and non-academic service quality. If students perceived good services from enrolment to post-graduation then they would most likely recommend that their friends enroll to the campus. Things to do on internal marketing are a) physical evidence (make available internal course textbook, sufficient learning facility, easy access to scientific journals, clean and comfortable classroom, and complete and accessible laboratory). b) People (mentoring lecturers are always concerned with the success of their students, department heads always help students in completing their study, campus staff is always attentive and helpful in serving student needs, library staff always helps students, and registration officers are friendly and very helpful to students). And c) Process (course materials match the syllabus, lecturing sessions are always on time, evaluation and final scoring are objective, availability of good learning online, and students are allowed to take examinations for upgrading their score).

\subsection{Limitations and future research directions}

There were some limitations of the research that should be admitted. First, we couldn't generalize the findings to all universities in the Republic of Indonesia, because the whole respondents came from only one province West Java. Whereas there were 34 provinces in the Republic of Indonesia. Second, the research findings would then be socialized and implemented, so communication with all stakeholders of universities is needed. Last, we recommended that follow-up studies on the same topic in different province(s) be carried out. They might apply a better method.

\section{Conclusion}

The research concluded the correlation among one set of marketing mix grouped into 2 areas: internal and external marketing in West Java Province, Indonesia. The research used an appropriate test and method approach so its findings really reflected the actual condition. The findings revealed that, according to students, place, product, price and promotion dimensions were the determinant of the success of failure in implementing external marketing at universities. Moreover, still according to students, physical evidence, people and process dimensions were the indicators of successful internal marketing in increasing student satisfaction and showing a good impression. By the findings, the students would recommend to potential students to enroll at the university. The correlation between external marketing and internal marketing was also positive and significant. University management should make sure that their internal and external marketing activities are going well so that students' and potential students' perception is also good.

\section{Acknowledgement}

We would like to thank the Minister of Education, Culture, Research, and Technology of the Republic of Indonesia, Mr. Nadiem Makarim who has provided financial support for this research. 


\section{References}

Abalala, T. S., Islam, M. M., \& Alam, M. M. (2021). Impact of ethical practices on small and medium enterprises' performance in Saudi Arabia: An Partial Least Squares-Structural Equation Modeling analysis. South African Journal of Business Management, 52(1), 11.

Afthanorhan, W. M. A. B. W. (2013). A comparison of partial least square structural equation modeling (PLS-SEM) and covariance based structural equation modeling (CB-SEM) for confirmatory factor analysis. International Journal of Engineering Science and Innovative Technology, 2(5), 198-205.

Ahmed, P. K., \& Rafiq, M. (2013). Internal marketing. Routledge.

Al-Fattal, A. (2010). Understanding student choice of university and marketing strategies in Syrian private higher education. University of Leeds.

Alwreikat, A. A., \& Rjoub, H. (2020). Impact of mobile advertising wearout on consumer irritation, perceived intrusiveness, engagement and loyalty: A partial least squares structural equation modelling analysis. South African Journal of Business Management, 51(1), 11.

Asiegbu, I. F., Igwe, P., \& Akekue-Alex, N. (2012). Physical evidence and marketing performance of commercial airlines in Nigeria. American International Journal of Contemporary Research, 2(12), 136-149.

Black, W., \& Babin, B. J. (2019). Multivariate data analysis: Its approach, evolution, and impact. In The great facilitator (pp. 121130). Springer, Cham.

Brkanlić, S., Sánchez-García, J., Esteve, E. B., Brkić, I., Ćirić, M., Tatarski, J., ... \& Petrović, M. (2020). Marketing mix instruments as factors of improvement of students' satisfaction in higher education institutions in republic of serbia and Spain. Sustainability, 12(18), 7802.

Cao, G., Duan, Y., \& Li, G. (2015). Linking business analytics to decision making effectiveness: A path model analysis. IEEE Transactions on Engineering Management, 62(3), 384-395.

Chawla, M. (2013). Customers (Students) perceptions about 7Ps of Higher Education Marketing Mix. Asian Journal of Multidisciplinary Studies, 1(5), 107.

Chen, C. W., Chen, W. C., \& Chen, W. K. (2014). Understanding the effects of eWOM on cosmetic consumer behavioral intention. International Journal of Electronic Commerce Studies, 5(1), 97-102.

Chrabanski, K. (2014). Economization of activities in the satisfaction survey process by means on-line electronic questionnaire systems. Acta Scientiarum Polonorum. Oeconomia, 13(1).

Christopher, M., Payne, A., \& Ballantyne, D. (2013). Relationship marketing. Routledge.

Domazet, I. S., Đokić, I., \& Milovanov, O. (2017). The Influence of advertising media on brand awareness. Management: Journal of Sustainable Business and Management Solutions in Emerging Economies, 23(1), 13-22.

Durkin, M., \& McKenna, S. (2011). Informing the marketing of higher education to younger people. Irish Marketing Review, 21(1), 41-47.

Filip, A. (2012). Marketing theory applicability in higher education. Procedia-social and Behavioral Sciences, 46, $912-916$.

Gajić, J. (2012). Importance of marketing mix in higher education institutions. Singidunum Journal of Applied Sciences, 9(1), 2941.

Goi, C. L. (2009). A review of marketing mix: 4Ps or more. International Journal of Marketing Studies, 1(1), 2-15.

Goodhue, D. L., Lewis, W., \& Thompson, R. (2012). Does PLS have advantages for small sample size or non-normal data?. MIS quarterly, 981-1001.

Gordon, R. (2012). Re-thinking and re-tooling the social marketing mix. Australasian Marketing Journal, 20(2), $122-126$.

Hair, J. F., Sarstedt, M., \& Ringle, C. M. (2019). Rethinking some of the rethinking of partial least squares. European Journal of Marketing, 53(4), 566-584.

Hall, H., \& Witek, L. (2016). Conditions, contemporary importance and prospects of higher education marketing on the example of Polish universities. Procedia Economics and Finance, 39, 206-211.

Hawkins, A. G., \& Frohoff, K. M. (2010). Promoting the academy-the challenges of marketing higher education. Research in Higher Education Journal, 7, 1.

Hirpassa, M. (2015). The Changing Role of the University TEFL Teacher in Improving the Students Communicative English Skill: From Passive Technician to Reflective Practitioner. Journal of Science and Sustainable Development, 3(1), $133-155$.

Huang, C. C., Wang, Y. M., Wu, T. W., \& Wang, P. A. (2013). An empirical analysis of the antecedents and performance consequences of using the moodle platform. International Journal of Information and Education Technology, 3(2), 217.

Išoraitė, M. (2016). Marketing mix theoretical aspects. International Journal of Research-Granthaalayah, 4(6), 25-37.

Kavididevi, K. R. (2009). Marketing of UK universities overseas: An evaluation study of Chester University, University of Huddersfield and Staffordshire University.

Kotler, P., Keller, K. L., Manceau, D., \& Dubois, B. (2016). Marketing Management, 15e édition. New Jersy: Pearson Education.

Lee, L., Petter, S., Fayard, D., \& Robinson, S. (2011). On the use of partial least squares path modeling in accounting research. International Journal of Accounting Information Systems, 12(4), 305-328.

Lim, W. M., Jee, T. W., \& De Run, E. C. (2020). Strategic brand management for higher education institutions with graduate degree programs: empirical insights from the higher education marketing mix. Journal of Strategic Marketing, 28(3), 225245.

Ndofirepi, E., Farinloye, T., \& Mogaji, E. (2020). Marketing mix in a heterogenous higher education market: A case of Africa. In Understanding the higher education market in Africa (pp. 241-262). Routledge.

Nfuka, E. N., \& Rusu, L. (2011). The effect of critical success factors on IT governance performance. Industrial Management \& Data Systems, 111(9). 
Ogunnaike, O., Tairat, B., Adeniyi, S., \& Omolade, O. (2014). Empirical analysis of marketing mix strategy and student loyalty in education marketing. Mediterranean Journal of Social Sciences, 5(23).

Pardiyono, R., \& Indrayani, R. (2019, April). Decision support system to choose private higher education based on marketing mix model criteria in Indonesia. In IOP Conference Series: Materials Science and Engineering (Vol. 508, No. 1, p. 012112). IOP Publishing.

Schulz, S. A., Martin, T., \& Meyer, H. M. (2017). Factors influencing organization commitment: Internal marketing orientation, external marketing orientation, and subjective well-being. Journal of Management Development, 36(10), 1294-1303.

Sekaran, U., \& Bougie, R. (2019). Research methods for business: A skill building approach. john wiley \& sons.

Shau, T. V. (2017). The confirmatory factor analysis (CFA) of preschool management model in Sarawak. International Journal of Academic Research in Business and Social Sciences, 7(6), 221-231.

Silaparasetti, V., Rao, G. V. R., \& Khan, F. R. (2017). Structural equation modeling analysis using smart pls to assess the occupational health and safety (OHS) factors on workers' behavior. Structural Equation Modeling Analysis Using Smart PLS to Assess the Occupational Health and Safety (OHS) Factors on Workers' Behavior (July 17, 2017). Humanities \& Social Science Reviews, eISSN, 2395-7654.

Singh, A. S. (2017). Common procedures for development, validity and reliability of a questionnaire. International Journal of Economics, Commerce and Management, 5(5), 790-801.

Singh, M. (2012). Marketing mix of 4P's for competitive advantage. IOSR Journal of Business and Management, 3(6), 40-45.

Sousa, B. B., \& Magalhães, F. C. (2019). An approach on attachment in public marketing and higher education management contexts. In Higher education and the evolution of management, applied sciences, and engineering curricula (pp. 151-171). IGI Global.

Stimac, H., \& Simic, M. L. (2012). Competitiveness in higher education: A need for marketing orientation and service quality. Economics \& Sociology, 5(2), 23.

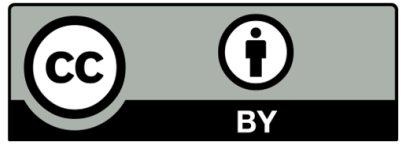

(C) 2022 by the authors; licensee Growing Science, Canada. This is an open access article distributed under the terms and conditions of the Creative Commons Attribution (CC-BY) license (http://creativecommons.org/licenses/by/4.0/). 